\title{
Building Translation Competence through Portfolios at Undergraduate Level - Reflections on a Practical Approach to Subtitling
}

\begin{abstract}
By Susana Amante*
This study focuses on reflections by students of 'English Translation Practice,' within the Study Plan of Languages and Business Relations at UTAD, Portugal, in 2018-2019. The main purpose is to 1. reflect upon the process of building Translation Competence through formal academic training; 2. discuss some of the difficulties that the students were faced with in a specific task, and the way they struggled and overcame their obstacles, thus 3. Proving that mediators between two languages and cultures are better prepared if they use more than just intuition and they have systematic training in the field. By comparing the students' translation of the last 00:05:47 of S03E05 of Forged in Fire (History Channel) and the original subtitles, we came to conclude that portfolios are key to understanding critical approaches to problematic situations; they are iterative and dynamic working documents that exemplify the students' search for solutions to their puzzlements and reveal fascinating insights into the development of Translation Competence.
\end{abstract}

Keywords: translation didactics, translation competence, subtitling, portfolios, critical reflection

\section{Introduction}

Nowadays, in an age of technological advances, in which Machine Translation (MT) may be thought to make a translator unnecessary and obsolete, some voices add to this tone standing out as being sceptical about the added value that formal translation training may bring to translators. There is no need to invest in something that is not needed, since technology does it all, some would say. Dietzel (2007), for instance, claims that "Machine Translation has more and more become an essential method to assist or even replace human translators" (p. 3, our italics) and Vasilescu (2014) argues that translators are now seen as MT post-editors whose work "has started to be regarded as less creative. Under the current circumstances, because of the new MT tools, translators are no longer supposed to have a particular gift for this work, or be walking encyclopedias as they used to be" ( $p$. 230). Therefore, in a way, this also undermines the idea that translators are naturally talented people, contrarily to what Eugene Nida had claimed in 1981, in an article entitled "Translators are born not made":

... even with special training in translation techniques, some people seem to have difficulty in grasping the principle of language equivalence. On the other hand, there

*Invited Associate Professor, School of Management and Technology, CI\&DEI, Polytechnic Institute of Viseu, Portugal. 
are people who would not seem to be potential translators, but who nevertheless do have hidden capacities for transferring messages from one language to another. With a certain amount of training these persons may master with remarkable effectiveness the required techniques (Nida 1981, p. 401).

Even if Nida believes in the innate capacities of individuals to exploit their creative imagination - the key element in translation, according to him, "to spot problems in the source-language text, including especially an ability to detect things which are difficult to understand and things which can have more than one meaning" (Nida 1981, p. 402), the fact is that he does not set training completely aside, but rather regards it as complementary. As he explains, “... a person who has some native ability in this area can always have his skills improved by training. But without some inborn capacity for understanding and transmitting messages, a person's potential as a translator will certainly be limited" (Nida 1981, p. 402).

The assertion that training is complementary to the process of building/ developing the necessary capacities for transferring messages from a source to a target language calls for a prior brief discussion of the concept of Translation Competence itself. As Orozco (2000) claims, the process through which this competence is to be constructed by students has not yet been sharply defined and, therefore, just like this scholar, we are going to focus on "[o]ne of the few models that does define the specific skills" (p. 199) associated with it and which was proposed by the Proceso de Adquisición de la Competencia Traductora y Evaluación (PACTE) research group (PACTE 2013). According to this group, Translation Competence implies a set of six sub-components that go well beyond the idea of linguistic competence to involve a) Communicative Competence in a source and target language - and within it, linguistic, discourse and sociolinguistic competence; b) Extra-Linguistic Competence, which activates general worldknowledge and more specific domain knowledge; c) Instrumental-Professional Competence, i.e., the ability to use the tools and skills associated with the practice of professional translation; d) Psycho-Physiological Competence, relating to attitudinal qualities, such as perseverance, rigour and intellectual curiosity, but also cognitive and psychomotor skills for reading and writing; e) Transfer Competence, which encompasses the knowledge of techniques, strategies and procedures at stake for a source text to be understood and re-expressed in a target language; and, finally, f) Strategic Competence, which is related to the pragmatic function of communication or, as Orozco (2000) puts it, with "all the individual procedures, conscious and unconscious, verbal and non-verbal, used to solve the problems found during the translation process" (p. 201). 
Figure 1. The Sub-Components of Translation Competence

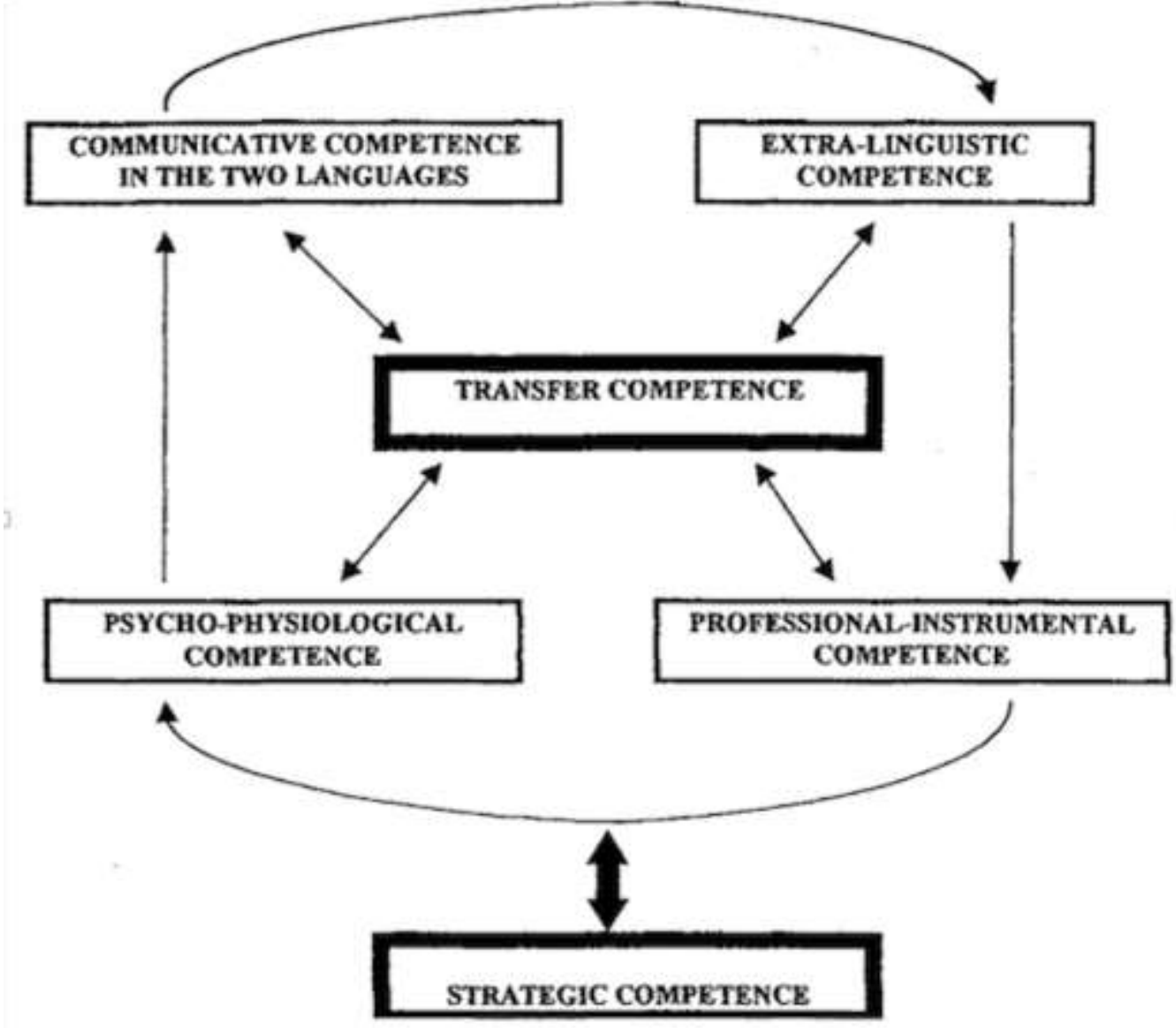

Source: Orozco 2000, p. 200.

But the question is more pressing than ever: why do we need to develop translation competence if the industry has been dominated by information technologies, in recent years, capable of retrieving data from a plethora of different sources much faster and at far lower cost, although, it is true, quality may also be sacrificed, at times?

Several studies (e.g., Christian 2011, Sofer 2013, Czopik 2014, Ghassemiazghandi and Mahadi 2014, Tergui 2016, Poibeau 2017) reveal that Machine Translation, the use of Computer-Assisted Translation (CAT) with its Translation Memories (TM) and other tools may not entirely replace human translation, since Information Systems are unable to think creatively; they just process data and the truth is that human language cannot be conceived of as merely a collection of signs and symbols easy to programme, manipulate and computerise. On the contrary, there is a great number of different layers of meaning that cannot be grasped if one does not have considerable knowledge of the language and culture of the source and target languages.

To prove this point that we need knowledge to be able to distinguish between the several meanings that a word may have depending on context, Umberto Eco makes use of a well-known example, and he claims: 
This term [bachelor] can be translated as soltero, scapolo, célibataire only within a human context, possibly concerning questions of marriage. Within a university context a bachelor is a person who has received a bachelor's degree (therefore it becomes a diplomato or improperly a laureato in Italian, or a licencié in French), and in a medieval context a bachelor is 'a young knight who follows the banner of another' - that is, in Italian, a baccelliere. Within a zoological context, a bachelor is 'a male animal, like a seal, without a mate during breeding time'. It is because of these contextual selections that, if I am given the English text John, a bachelor, who studied at Oxford, is now writing a PhD dissertation on the North Pole bachelors, I should not translate it into French as Jean, une foque sans copine qui s'est licenciée à Oxford, est en train d'écrire une these de doctorat sur les célibataires du Pole Nord..." (Eco 2003, p. 13).

We are not trying to undermine the validity and utility of these sources. All these necessary tools contribute to the translational process just like arithmetic is nowadays aided by calculators and research is aided by the internet. As Chesterman (2000, p. 80) puts it, using another analogy, "Translating is like, say, carpentry, in that both are skills and both need tools. Some translation tools are physical (computer aids etc.) and some are conceptual". Recognising the everexpanding potential of technology, O'Brien (2012) came to characterise professional translation as being a part of a complex network that requires humancomputer interaction (HCI).

Aware that HCI practices are inevitably taking place, the question as to whether formal training is really necessary, or learning through experience is enough, leads us once again to revisit the idea of translation as a natural ability or as an acquired skill.

Even if there is no doubt that some successful and highly skilled translators in the industry have educated themselves, recent studies show that there is more to be gained from formal training, because of the backbone functions it may serve. Particularly, Gile identifies two:

One is to help individuals who wish to become professional interpreters or translators enhance their performance to the full realization of their potential. The other is to help them develop their translation skills more rapidly than through field experience and self-instruction, which may involve much groping in the dark and learning by trial-and-error (Gile 2009, p. 7).

Translation Competence can indeed be taught, and many scholars have proven that the best place to effectively develop and train the skills associated with it is an academic institution. Baker (2011), for instance, sides with Lanna Castellano and she even quotes her to say that there is an alternative path to formal academic training - life experience, but, just like Gile, she immediately emphasises that such journey is much longer and harder to reach than if one is guided into the whole process through theoretical knowledge complemented by practice, both gained in university settings. Pym (2014) also highlights this very same idea when he points out that there are good translators who have never taken a translation course, but he is ready to clarify that "awareness of different theories might be of 
practical benefit when confronting problems for which there are no established solutions, where significant creativity is required" (p. 4).

In this study, we would also like to add to the controversy that stirs up around the usefulness of (theoretical classes as part of) a translator-training programme, by trying to understand the reflective and hermeneutical approaches to knowledge and the dynamics of networking among translation students. Particularly, this article describes the results of a qualitative research by analysing the difficulties that three groups of students studying at the University of Trás-os-Montes and Alto Douro, in Portugal, felt in one of the portfolio tasks that they had to undertake and that was related to audiovisual translation, together with critical reflections upon the process of subtitling.

In the next few pages, the method will be presented, and, for that purpose, we will describe the participants, the instruments, the research objectives and we will briefly explain how we collected the data for this study. An analysis of the main findings and discussions will follow.

\section{Method}

\section{Participants}

The research involved a class of eleven third-year students who chose the optional course unit 'English Translation Practice', offered as part of a Degree in Languages and Business Relations, at the University of Trás-os-Montes and Alto Douro (UTAD), in Portugal, in the second semester of the academic year 20182019. However, out of these eleven students, one of them signed up for this and other course units, but he never showed up in any of the lessons. Another student decided to take a year off after a couple of months, because he encountered some problems in his internship and, therefore, felt he needed a break from University. As he completed three tasks only, he did not reach the one that we are using in this research and, therefore, he will not be considered for this study. A last student that will not be taken into consideration is one that belongs to a student leadership group who did not attend the majority of the lessons and did not deliver his portfolio.

It is important to mention that this elective course unit is preceded by 'Theories and Techniques of Translation,' a compulsory unit in the first semester, taught by another Professor in the school year under analysis. Also relevant is the fact that the participants' level is estimated at, at least C1.1., due to their completion of 'English C1.1.' in the first semester. At that time, the eight students had signed up and were attending English C1.2. classes.

\section{Instruments}

\section{$\underline{\text { Portfolio }}$}

The Portfolio tasks included different text-types that ranged from excerpts from inflight magazines, to contracts, lyrics, culture-specific texts such as legends, 
recipes, children's literature, jokes and anecdotes, and even the addition of interlingual subtitles to an excerpt of a TV show, which required specific knowledge of norms and guidelines. The languages that were used as both SL and TL were Portuguese and English, interchangeably. In many of the lessons, the students were invited to sit in groups to engage in active learning. Rather than a monologic teaching atmosphere, preference was given to dialogic learning, where students were required to solve a given task, by discussing possibilities and deciding what worked best, always getting instant and tailored feedback from the professor whenever they needed, or when the latter challenged them to think creatively and critically, based on theories, techniques and data analysed beforehand, in classes. All the tasks, in-class and coursework at home, were later compiled into a portfolio, as we believe that it is an effective document that helps students reflect on where they started, their learning progress, outcomes and what remains to be learned and applied. It is also an instrument that the students can keep and resort to whenever they need, beyond the academia, laying the groundwork for lifelong learning, while, for the professor, it provides better evidence of achievement of the learning outcomes. Galán-Mañas (2016) summarises all these ideas, pointing out that, "Within academic institutions, not only do they [portfolios] showcase students' work, they also serve to develop reflective and critical thinking skills, and to assess performance".

We recognise that this analysis would benefit from a closer examination of other tasks mentioned above, but we decided to focus on a subtask only, among the ten tasks requested, since this one, in particular, provides the students with the opportunity to ponder over their success in meeting the standards set out in the course unit programme:

The main aims of this CU are outlined as follows ${ }^{1}$ :

- To provide an opportunity to practise the translation of various texts.

- To expose the students to various translation procedures and methods.

- To focus on different areas such as context and register, language functions and text types.

- To focus on translation equivalence at the level of word, grammar and text.

- To know how to deal with specific theme-related terminology, collocations, 'false friends', idioms and culture-bound terms.

- To develop the necessary skills/tools for the activity of translation.

Therefore, data collection is based on Task 4c. - Reflection on the students' subtitling task - last 00:05:47 of Season 03, Episode 05 (S03E05) of Forged in Fire (History Channel) - and the original subtitles: comparative analysis. We believe that this reflection looks both backwards, at the strengths and weaknesses

\footnotetext{
${ }^{1}$ https://side.utad.pt/cursos/empresariais/servicos/docentes/fichacurricular.
} 
of the work and skills developed, measured against professional subtitling, and also forward, at the potential for future improvement. The best way for the students to undertake this task was, from our point of view, in their own language, because we wanted this reflection to be in their own terms, so that they could express their feelings and thoughts as naturally as possible, without overthinking or hesitation.

Analysis of the reflective commentaries on the subtitling task forms part of the discussion of the section 'Findings and Discussions'.

\section{Research Objectives}

The purpose of this study is, then, 1. to reflect upon the process of building/ developing Translation Competence through formal academic training; 2 . discuss some of the difficulties that the students were faced with in a specific task, and the way they struggled and overcame their obstacles, thus 3. proving that mediators between (at least) two languages and cultures are better prepared if they use more than just intuition or any other innate qualities and they have systematic training in the field.

\section{Data Analysis}

As mentioned above, we do believe that portfolios are a valuable source of information for both the students and the instructor(s), as they are a metacognitive endeavour that captures the process rather than just the result, that is, the emphasis is put not only on the products to be evaluated - the translations themselves -, but on the effort, the knowledge construction, the ability to reflect on action to improve practice and the progress made by the students. That is the reason why portfolio tasks that involve critical reflection and analytical thinking are thought to support learning, instead of simply measuring it. As Dewey (1933, p. 24) once put it, "[i]t converts action that is merely appetitive, blind and impulsive into intelligent action".

In this study, the data analysis was conducted qualitatively, by identifying similar ideas or common problems that were highlighted by each group of students. On the other hand, we also considered opposing views to understand more fully all positions or opinions. We identified and extracted from the portfolio Task 4c., the most significant quotations that were used as evidence to answer our research objectives and we tried to bring expert knowledge on our interpretations, by focusing on existing literature on the subject matter.

\section{Results and Discussion}

In this section, we will present the discussion of the findings for each of the research objectives.

The students' reflections regarding the fourth portfolio task provide us with a window into the development of their Translation Competence. In fact, by 
comparing the students' translation of the last 00:05:47 of S03E05 of Forged in Fire (History Channel) and the original subtitles, we noticed that a group of students was able to discuss some of their translation decisions, for instance regarding the use of loanwords:

In one of the parts, it is mentioned that "it's all about how they hold up in our weapons test"; we decided to use the loanword "performance", because although desempenho ["performance'] can be used, the [English] word "performance" is already prevalent in the Portuguese vocabulary and, from our experience, it is the most commonly used word when we talk about desempenho ['performance'] in tests (Students A \& B - our translation $)^{2}$.

Even if they do not mention where they got their experience from, whether it is from their educational background and training or from general impressions, they clearly point out to the specific context of testing weapons and, thus, we can say that this use of the borrowing technique was intentional and justified by register. This use becomes even more interesting if we bear in mind that the word is used as a natural choice, when it is not part of the ST, which reads: "Fantastic. Both weapons look amazing, but as we all know it's all about how they hold up in our weapons test" (00:00:30,087 - 00:00:36,788). This group's translation read "Fantastic. Both seem incredible, but as we know the important thing is 'performance' in tests" (back-translation of the students' subtitles in Portuguese), while the TV show subtitles showed the following translation: "Fantastic! The weapons look incredible! But as we know everything depends on the tests",3 (backtranslation of the Portuguese subtitles by professional subtitlers). Other groups opted for a more literal translation, such as "Fantastic! Both weapons look incredible, but, as we know, it all comes down to holding up in our weapons tests." (Students F, G \& H - our translation) or as "Fantastic! Both weapons look incredible, but, as we know, it all comes down to how they behave in the test" (Students C, D \& E - our translation).

Also, concerning the register, the first group of students made once again use of a communicative competence in interaction with extra-linguistic, transfer, psycho-physiological and strategic competences when, somewhat overconfidently, they assert:

As to good options in the original, we don't think any of the ones they took is better than ours or we would have taken it ourselves. But one of the parts that caught our attention was when he translated [“... we pretty much took care of that skull” as] "...

\footnotetext{
${ }^{2}$ ["Numa das partes é referido "it's all about how they hold up in our weapons test", escolhemos utilizar um estrangeirismo com a palavra "performance" porque apesar de poder ser usado "desempenho", a palavra "performance" já é corrente no vocabulário português e pela nossa experiência é a mais usada quando falamos de desempenho em testes."]

${ }^{3}$ ["Fantástico. Ambas parecem incríveis, mas como sabemos o importante é a 'performance' nos testes."]

${ }^{4}$ [Fantástico! Ambas as armas parecem incríveis, mas como sabemos, resume-se tudo a aguentarem os nossos testes de armas.]

${ }^{5}$ [Fantástico! Ambas as armas parecem incríveis, mas como sabemos tudo se resume a como se comportam no teste].
} 
we tore that skull apart"; we liked it, it fits into the atmosphere of the TV show (Students A \& B - our translation) ${ }^{6}$.

This comment reveals that these students critically deliberated on their translation to find that it was not as natural or accurate as the one in the subtitles, in this particular chunk, because they translated it as "... we destroyed the skull", and they felt an idiom would be a much better solution.

The other two groups also show a similar relative confidence in their work, even if they recognise more difficulties at times, as we are going to discuss further on. Students F, G \& H expressed satisfaction for having paid more attention to extra-linguistic factors and for having used instrumental-professional competence, as they evaluate in the following terms:

After being granted access to the subtitles by the History Channel, we concluded that there are some differences between the two translations, but that does not make our translation worse than the other, as we learned in class. Generally speaking, we believe our translation is actually the most appropriate, as some instances show, such as the minute $1: 18$, in which we decided to translate "handle" as "punho [hilt]" because according to our research that area should be referred to as the sword hilt and not "cabo [handle]" as mentioned and as translated (Students F, G \& H - our translation).

These students feel proud for having polished not only the subtitles but also the original text. This group's portfolio was illustrative of the students' commitment and willingness to learn and apply taught strategies as they resort to previous lessons to solve problems, but also to external support, as mentioned. Below, we can find another example of the way they took decisions:

Regarding the money, we decided to translate the amount into euros, in order to adapt it to a Portuguese audience, but this wasn't without much discussion about it, since one of us wanted to simply omit the currency and we also thought about maintaining the amount in dollars or using interpolation, as we did in class, when explaining dishes, but then we decided that this translation wouldn't create an obstacle. When we're referring to translation, we're not referring to currency conversion, which would actually be more correct, but then the sum wouldn't be an integer. In the original version they kept the amount in dollars, probably because it was the easiest way out, but our version is not wrong as the amount isn't that different and, on the other hand,

\footnotetext{
${ }^{6}$ [Quanto a opções corretas no original não achamos que nenhuma das que fizeram seja melhor que a nossa, senão tínhamo-la feito nós. Mas uma das partes que nos chamou a atenção foi quando ele traduz "demos cabo daquele crânio"; gostámos, enquadra-se com a atmosfera do programa.]

${ }^{7}[$ [... destruímos o crânio].

${ }^{8}$ [Após termos acesso à legendagem feita pelo canal História concluímos que existem algumas diferenças entre as duas traduções, o que, segundo aprendemos nas aulas, não faz da nossa tradução a pior.

No geral consideramos que a nossa tradução até é a mais adequada, como se verifica em algumas instâncias, como no minuto 1:18 em que optamos por traduzir "handle" como "punho" pois segundo a nossa pesquisa essa zona deve ser referida como o punho da espada e não "cabo" como foi mencionado e traduzido.]
} 
without a translation, the audience could think that $\$ 10,000$ is much more/less in euros.

In certain parts of the subtitles, we also decided to punctuate the text differently to give more emphasis to what is being said (Students F, G \& H - our translation) ${ }^{9}$.

The first group [students A \& B] discusses the amount of money, not in terms of currency, but the way it is visually presented: "Another aspect in which we could have followed the original is when we translated 'ten thousand dollars' to ' 10,000 dollars'; maybe we should have followed the original and translated it in full because it is more pleasant to read" ${ }^{\prime 10}$. The fact, however, is that Diaz-Cintas and Remael (2007, p. 135) do recommend to "write these long numbers with a comma in English, since this helps reading them on screen."

Students C, D \& E are perhaps the ones that side much more often with the subtitler(s) and, while examining the decisions they took, they criticise the fact that they were not as close to the original as they believe they should have been, as in the following example:

Right at the beginning of the video, to translate 'Josh, would you tell us a little bit about your Kora?', (...) we translated it as 'Josh, tell us a little bit about your Kora.'

Our choice is due to an attempt to make the subtitles as short as possible. We have to acknowledge, though, that there was no need to turn an interrogative sentence into an imperative sentence. The translators' option works best, in our view (our translation) ${ }^{11}$.

The same view is suggested by Karamitroglou (1998, 2000), among others, as he believes that audiovisual translation products should be analysed not only in terms of adequacy and acceptability, but also, and more importantly, in terms of conformity and deviation from target norms.

As noted, after having seen the original, the students adopt a negative stance on the changes they had made and they abandon their option just because they feel there is a need for total concordance and they ignore that, by adjusting the types of

\footnotetext{
${ }^{9}$ [Na parte do dinheiro, nós optámos por legendar o valor em euros, para adaptarmos a um público português, mas isso não foi sem discussão, pois uma de nós queria simplesmente omitir a moeda e também pensámos em manter o valor em dólares ou usar interpolation, como fizemos na aula quanto aos pratos, mas depois decidimos que esta tradução não iria criar problemas. Quando nos referimos à tradução, não é a conversão de moeda, o que na verdade seria o mais correto, mas depois não dava um número inteiro. Na versão original, eles mantiveram o valor em dólares, provavelmente porque era a forma mais fácil, mas a nossa versão não está errada porque o valor não é muito diferente e, por outro lado, sem tradução, o público poderia ser pensar que $\$ 10.000$ é muito mais/menos em euros.]

Em certas partes da legenda decidimos também por pontuar de forma diferente para dar mais ênfase ao que está a ser dito.]

${ }^{10}$ [Outro aspeto em que podíamos ter seguido o original é quando traduzimos 'ten thousand dolars' para '10.000 dólares'; talvez devêssemos ter seguido o original e traduzir por extenso pois fica mais agradável para a leitura.]

${ }^{11}$ [Logo no início do vídeo, para traduzir 'Josh, would you tell us a little bit about your Kora?', (...) nós traduzimos como "Josh, fala-nos um pouco da tua Kora.".

A nossa opção deve-se a uma tentativa de tornar a legenda o mais curta possível. Temos, todavia, de reconhecer que não havia necessidade de tornar uma frase interrogativa numa frase imperativa. A opção dos tradutores funciona melhor, a nosso ver.]
} 
sentences, from interrogative to imperative, they are pragmatically making the same request for verbal action, in terms of illocutionary force, both resulting in a perlocutionary act in which Josh does tell the TV presenters a little bit about his kora. Obviously, there is a difference in formality, as the students' version does not follow Leech's politeness principle (2014), thus lacking the attitudinal warmth and refinement that characterises TV shows, but by being much more direct they are, in fact, as they say, making the subtitles shorter, which would be a plus, if needed. This fact was discussed with the students afterwards, for them to see that they had intuitively adopted the strategy of modulation, that is, they changed the point to view to express the same idea in a different way.

Prior to this reflection task, this group of students also ignored that subtitles frequently omit lexical items from the source text, namely exclamations, because of the shifting roles of oral and written forms of communication, as we can see in the following comment:

On a more technical level, there is a part, at minute 00.03.15, where Josh says 'Yeah' and we decided to translate it as 'right' in our task. We now acknowledge that it should have been as in the original and [we should have] ignored this 'yeah', because it needlessly cuts the subtitle in half. The same happens before, at minute 00.00 .17 of the original video, where the utterance 'Great' is omitted while in our translation we translated it as follows: 'Excellent!'

Finally, at minute 00.02 .46 of our captions we wrote the subtitle corresponding to 'Ok' while in the original video it is omitted (Students C, D \& E - our translation) ${ }^{12}$.

Another group also reflects on this topic, but the members seem to be more at ease with omissions. Students A \& B mention that...

At minute $00.00 .10-00.00 .13$ of the original video, the subtitle presented is 'I made a whole steel handle, whole steel construction; that's what I found the originals to be.' In our subtitles, we decided to omit part of the utterance resulting in the following 'I made it all in steel, like the originals.' We guess it didn't lose meaning and, though freer, it's less intrusive, allowing the TV show to be seen with less friction (our translation $)^{13}$.

\footnotetext{
${ }^{12}$ [Num ponto mais técnico há uma parte, no minuto 00.03.15, em que o Josh diz 'Yeah' e nós resolvemos traduzir como 'pois' no nosso trabalho. Reconhecemos agora que devia ter sido feito como no original e ignorar esse 'Yeah' pois corta ali uma legenda a meio sem necessidade nenhuma. $\mathrm{O}$ mesmo acontece antes, no minuto 00.00.17 do vídeo original, em que a fala 'Great' é omitida enquanto que na nossa tradução legendámos da seguinte forma 'Excelente!'. Por fim, no minuto 00.02.46 da nossa legendagem nós colocámos a legenda correspondente ao 'Ok' enquanto que no vídeo original essa legenda é omitida.]

${ }^{13}$ [No minuto 00.00.10 - 00.00.13 do vídeo original a legenda apresentada é 'Fiz um cabo em aço, todo em aço. Descobri que os originais eram assim.' Na nossa legenda decidimos omitir parte da fala resultando na seguinte 'Fiz tudo em aço, como as originais.' Achamos que não perdeu sentido e, embora seja uma tradução mais livre, é menos intrusiva, permitindo o visionamento do programa com menos atrito.]
} 
These two students are well-aware that subtitlers should be careful not to sacrifice the audiovisual translation in favour of verbatim subtitles, but they also know that any changes ought not to subtract, add or obscure meaning. Condensation or even total reduction, that is, deletion, should not be a problem as long as subtitlers " $\ldots$ act on the principle of relevance (...), striving to capture the essence of what is said while making sure that no information of crucial diegetic value is deleted", as Diaz-Cintas claims (2015, p. 277). Earlier, this same scholar had already discussed the same idea, when, together with Remael, stated that what is important is that the audience enjoys the semiotic whole and, for that purpose, it is true that

Grammar and lexical items tend to be simplified and cleaned up, whereas interactional features and intonation are only maintained to some extent (e.g., through word order, rhetorical questions, occasional interjections, and incomplete sentences). In other words, not all the features of speech are lost, quite a few can be salvaged in writing, but rendering them all would lead to illegible and exceedingly long subtitles. Since subtitling focuses on those items that are informationally most relevant, often context renewing clauses are retained, whereas context confirming ones are dropped (DiazCintas and Remael 2007, pp. 63-64).

We noticed that students, generally speaking, did not feel the urge to be creative. The translation of jokes and anecdotes (task 2), for example, or of the lyrics "Contigo", by Carolina Deslandes and Jimmy P. (task 3a) and the subsequent task 3b., 'Translation of the lyrics in 3.a. but taking into consideration the rhythm of the song (cf. number of syllables; use of rhymes; ...) to make it singable", implied much more creativity. The reason why we do not present the data gathered in this study is because each one of these tasks would provide us with lengthy transcripts and analyses, which can be the focus of future work.

Punctuation was an area on which all the groups focused, because they found that they used different punctuation conventions, as we had already shown above and as the following comment also illustrates:

Between minute 00.03.51 and 00.03.54, in our subtitles, we used 'It looks like... like death', while in the original video they decided to go with the sentence with no punctuation in the middle: 'It looks like an Instrument of Death'. In this case, we used the three dots to demonstrate the thinking pause of the jury when they went to evaluate the Kora's appearance. (...)

At minute 00.04.29 of our subtitles, we decided to use three dots instead of the period, in order to show suspense before the winner's name is announced (Students C, D \& E - our translation $)^{14}$.

The same is argued by the other group when they point out:

\footnotetext{
${ }^{14}$ [Entre o minuto 00.03.51 e 00.03.54, na nossa legenda, nós utilizámos "Tem a aparência de... como se fosse a morte" enquanto que no vídeo original decidiram seguir com a frase sem a pontuação no meio "Tem a aparência de Instrumento da Morte". Neste caso, colocámos as reticências para demonstrar a pausa para pensar que o júri fez quando foi avaliar a aparência da Kora. (...) No minuto 00.04.29 da nossa legenda, decidimos colocar as reticências em vez do ponto final, de modo a demonstrar suspense pela divulgação do vencedor.]
} 
Even then, when you say 'But... like Doug said, the handle wants to roll in my hand,' we decided to use ellipsis marks to mark the hesitation shown by the speakers. The translators decided not to mark that hesitation at all. We believe our option is the most correct one.

Upon the utterance 'You know, this thing once you get it started it's gonna go,' Josh answers 'Right' and takes up the previous utterance: 'My only worry is stopping it. We ignore Josh's utterance in the subtitling work, just like the translators. We include ellipsis marks to mark a hesitation, as already mentioned, unlike the translators (Students A \& B - our translation) $)^{15}$.

Pauses, hesitations and silences are usually marked by ellipsis marks, as DiazCintas and Remael explain: "Another function attached to the three dots is the same as in other written texts, i.e. to indicate prosodic features like pauses and hesitations in the way speakers deliver their utterances" (2007, p. 113). However, it should be noted that it is not really a solid Portuguese tradition.

Interestingly, regarding the form of addressing among all the TV show participants, two groups opted for a degree of familiarity and closeness between speaker and addressee, by using the second person singular, while one group inconsistently uses the second and sometimes the third person forms to imply social distance or an attitude of respect/deference between interlocutors, maybe because Josh is a young man.

In regard to difficulties, this same group [students $C, D \& E$ ] acknowledges their lack of consistency at times, probably resulting from the fact that the decisions were taken by three different students that, instead of working together, discussing differing points of view, took separate ways in some of the lessons, either because they wanted to finish the task sooner, or because by dividing the tasks they would not have as much work or simply because they trusted the others' decisions: "We must make a final caveat; we made a mistake in our subtitling task. We were not consistent in our subtitling task, namely because we sometimes opted for 'cabo' and some other times for 'punho""16 (Students C, D \& E - our translation). They are aware of the need for consistency in terminology, even if identification of the referent seems not to suffer from an alternative use of these two closely related terms. As previously seen, the choice of the best term regarding this same pair of words had been the focus of another group's reflection, the same group that also pointed out the following difficulties:

'The full ring you did on the spine' was an expression that was hard for us to translate and we felt that the teacher's guidance followed by the dialogue among the members

\footnotetext{
${ }^{15}$ [Mesmo de seguida quando se diz 'But... like Doug said, the handle wants to roll in my hand', nós optámos por utilizar as reticências para marcar a hesitação evidenciada por quem fala. Os tradutores decidiram-se por não marcarem de todo essa hesitação. Consideramos a nossa opção mais correta. Quando se diz 'You know, this thing once you get it started it's gonna go', o Josh responde 'Right' e retoma-se o discurso anterior 'My only worry is stopping it.' Ignoramos a fala do Josh no trabalho de legendagem, à semelhança dos tradutores. Incluímos reticências para marcar uma hesitação, como já foi referido, ao contrário dos tradutores.]

${ }^{16}$ [Importa fazer uma última ressalva, cometemos um erro na nossa legendagem. Não fomos consistentes na nossa legendagem, nomeadamente por algumas vezes termos optado por 'cabo' e outras vezes por 'punho'.]
} 
of the group was the driving force to overcome the difficulties. We did some research and 'full ring' could refer to ornamental rings that were placed on the back of the blade or the shape of the blade itself. We chose 'curvatura [curvature]' because, due to the lack of a direct equivalent in Portuguese, we thought that this word fits the appearance of the sword in question. Also, an expression used in this part is 'eye candy', which could be misunderstood by a layman and Google Translate itself contributes to this misunderstanding, because it translates [the expression] as 'colírio para os olhos [chloride drops]'. There's a lot of nonsense in subtitling because translators often use this tool with no critical stance. 'Eye candy' refers to something that's pleasant to look at, as the name implies, a candy for the eye (Students F, G \& H - our translation $)^{17}$.

By trying to translate the expression above using Google Translate, the students noticed that it simply did not work for this particular case, and they had to use other strategies, because this saline solution did not fit the context and so they searched for idioms. Nida, on this point, reminds us that "A failure to recognize figurative expressions may result in a translation which is completely absurd" (Nida 1981, p. 403).

In this light, we can say that by 2 . discussing some of the difficulties that the students were faced with in this specific task, and the way they struggled and overcame their obstacles, they are inevitably 1. reflecting upon the process of building/developing Translation Competence through formal academic training. This portfolio task enables these groups of students to grow intellectually, even those that do not show as much curiosity and who seem not to conduct research or discuss techniques to solve problems. The second group of students [C, D \& E] is well-aware, at the end of the process, that their portfolio could have benefitted from the discussion of various views, various sources, and from proof-reading and revision of their translations:

All in all, this work has failed in many ways and this is because we wanted to keep our voice, which cannot happen when the translation is one and must be coherent. Each one has their own personal style, but if $[\mathrm{D}]$ and $[\mathrm{C}]$ are better at languages and $[\mathrm{E}]$ is more disciplined and reflective, then we should take advantage of each other's characteristics instead of putting together the parts of the translation like a puzzle whose pieces then won't fit. We thought that translators work very much on their own and we wanted to do the same, but this is not possible in a joint work, in a

\footnotetext{
${ }^{17}$ ['The full ring you did on the spine' foi uma expressão que nos custou a traduzir e sentimos que a orientação da professora seguida do diálogo entre o grupo foram o motor para conseguirmos ultrapassar as dificuldades. Fizemos uma pesquisa e 'full ring' podiam ser anéis ornamentais que se punham na parte de trás da lâmina ou podia ser o formato da lâmina em si. Escolhemos 'curvatura' pois, à falta de um equivalente direto em português, pensamos que a palavra se adequa ao aspeto da espada em questão. Também uma expressão usada nessa parte é 'eye candy', que podia ser mal-entendida por um leigo e o próprio Google Translate ajuda à confusão, porque traduz como "colírio para os olhos". Há muita asneira em legendagem porque os tradutores recorrem frequentemente a esta ferramenta sem um olhar crítico. 'Eye candy' refere-se a uma coisa que é agradável de olhar, como o nome indica, um doce para a visão.]
} 
teamwork, not least because the grade is the same for everyone... (Students C, D \& E - our translation $)^{18}$.

It should be noted that, even if the students recognised that they should have taken advantage of groupwork, they tried to justify their option with their perceptions regarding a translator's professional activity and, besides that, their main concern seems to be their evaluation. They totally forgot that, as mentioned in class, "[s]ubtitling is the result of a team effort" (Diaz-Cintas and Remael 2007, p. 29) and that they could be connected by means of, for example, cloud subtitling. However, these students' perception is not very different from the way that fansubbers operate, at least in Italy, that is, "[e]ach fansubber is assigned a specific part of the episode; when the translations of the parts are ready, the revisor collects the various files and merges them, editing and homogenising them for consistency" (Massidda and Casarini 2017, p. 68). The group's problem, more than dividing the tasks, was that they did not communicate among themselves and they totally forgot the last part of any project, revision. Probably because two of these students are actually very good at languages, they took for granted that the course unit would cause no difficulties, something they learned not to be exactly as they figured out, especially as to subtitling:

Because we had never worked with any subtitling software and because we had never had the chance to understand the inherent difficulties of subtitling before, we have taken several options that were not the best in terms of line splitting in subtitling, the size of the captions and the synchronisation of the captions with the video, although we were taught these technical rules, theoretically in classes, before putting things into practice (Students C, D \& E - our translation) ${ }^{19}$.

Actually, theory and practice do not always align in reality and the same restraints were evidenced in the third group's testimony with respect to the arduous nature of subtitling:

In doing this subtitling task we came across some problems that a translator faces that were not so obvious to us before. More than translating, we need to pay attention to technical aspects such as the size of the caption, the speed with which it is shown, etc. In some situations, we translated the text in a way that, despite not incorrect, goes against subtitling rules. We tried to render a translation that was in line with the

\footnotetext{
${ }^{18}$ [No cômputo geral, este trabalho falhou em muitos aspetos e isso aconteceu porque queríamos manter a nossa voz, o que não pode acontecer quando a tradução é uma só e deve apresentar coerência. Cada um tem o seu estilo pessoal, mas se o $[\mathrm{H}]$ e o $[\mathrm{G}]$ são melhor em línguas e a F é mais disciplinada e reflexiva, então devemos aproveitar as características de cada um em vez de juntarmos as partes da tradução como um puzzle que depois não encaixa. Achávamos que os tradutores trabalham muito sozinhos e queríamos fazer igual, mas isso não é possível num trabalho conjunto, num trabalho de equipa, até porque a nota é a mesma para todos...]

${ }^{19}$ [Por nunca termos trabalhado com nenhum programa de legendagem e por nunca termos percebido a dificuldade inerente a uma legendagem tomámos várias opções que não foram as melhores no que diz respeito à divisão das falas na legenda, ao tamanho da legenda e à sincronização da legenda com o vídeo, embora tenhamos aprendido estes aspetos técnicos em teoria nas aulas, antes de as pormos em prática.]
} 
original, but we should have synthesised more in some parts to make it easier for the reader of the subtitles to follow them" (Students F, G \& H - our translation) ${ }^{20}$.

In classes, the students were shown some examples and they talked about some apps and specific (freeware) software that could be used to create the captions. Many of these already include the rules and other technical parameters required to complete the subtitling task, but nonetheless accurate timing was difficult to achieve, as the first group also complains:

We had some problems of synchronization due to the fact that sometimes the speed of the speech was very fast-paced and connected, which made it impossible to write the subtitles in a perceptible and synchronized way and that led us sometimes to omit some parts (which we believe not to have affected the utterances produced and their intelligibility, as mentioned above) (Students A \& B - our translation) ${ }^{21}$.

These are but some of the difficulties that the students were faced with in this task, and we have just seen the way they struggled and overcame their obstacles. The students, while mediators between Portuguese and English, could notice that knowing the languages and cultures of both source and target texts is not enough and that systematic training in the field is a plus, proving our third aim, because there is much more to translation than simple linguistic transfer. We cannot resist ending this section using the students' own words, on this matter:

To conclude, we should note that subtitling has opened our eyes to the difficulties of a translator. Translating is just one of the translator's duties. Information, research and adaptation are just as important (or even more) as mastering two languages. In addition, it is necessary to pay attention to aspects that are not even related to translation, such as the use of computer tools like the one we used to complete this work. A translator has to be like a chameleon and adapt to the different situations presented to him or her, be it a subtitling task, the translation of a song or the adaptation of a novel, and each one of them has specific components that cannot be easily transported (Students F, G \& H - our translation) ${ }^{22}$.

\footnotetext{
${ }^{20}$ [Ao fazer esta tarefa de legendagem deparámo-nos com alguns problemas que um tradutor enfrenta e que não nos eram óbvios antes. Mais do que traduzir é necessário ter atenção a aspetos técnicos como o tamanho da legenda, a rapidez com que ela se passa, etc. Em algumas situações fizemos uma tradução que apesar de não estar mal entra em conflito com as regras da legendagem. Tentámos fazer uma tradução que estivesse em sintonia com o original, mas deveríamos ter sintetizado mais em algumas partes para ser mais fácil ao leitor das legendas de as seguir.]

${ }^{21}$ [Tivemos algumas dificuldades na parte da sincronização devido ao facto que por vezes o discurso era muito rápido e seguido um ao outro, o que impossibilitava a colocação de legenda de forma percetível e sincronizada o que nos levou de certa forma, por vezes, a omitir algumas partes (que julgamos não afetar as falas e a compreensão das mesmas, como referido acima).] ${ }^{22}$ [Para concluir é de referir que legendagem nos abriu os olhos para as dificuldades de um tradutor. Traduzir é apenas um dos deveres do tradutor. Informação, pesquisa e adaptação são tão ou mais importantes do que conhecimento de duas línguas. Além disso é necessário ter atenção a aspetos que não estão sequer relacionados com tradução, como utilização de ferramentas informáticas como a que usámos para fazer este trabalho. Um tradutor tem de ser como um camaleão e adaptar-se às diferentes situações que lhe forem apresentadas, seja uma
} 


\section{Conclusion}

In this study, a specific task of the students' portfolios - the reflection upon subtitling - provided a comprehensive and practical discussion of the process of building and developing Translation Competence, a multi-layered phenomenon that integrates several dimensions that go beyond the linguistic, extra-linguistic and cultural knowledge, but also requires strategic, instrumental-professional, transfer and psycho-physiological sub-competences. Departing from the idea that the students and so many other people have regarding translation, which is its simplicity, since it only implies the rendering of a text into another language, so they say/said, we subscribed to the opinion of those who argue against inspiration in translation, and side with perspiration, to follow Thomas Edison's famous words when he mentions that "Genius is 1 percent inspiration and 99 percent perspiration", as quoted by Belsky (2010, p. 94), or, even better, it is the dynamic interplay of both forces.

It was evident, throughout this analysis, that students have recognised the important role of formal education and training to achieve Translation Competence, which means that Chesterman's words remain true twenty years after being first written:

An expert translator is seen as someone who works largely on intuition, on automatic pilot as it were, but who retains the ability to draw on critical rationality when the need arises, for instance in solving particularly tough or unusual problems, or when justifying solutions to the client. (...) At the beginning, certain rules and concepts have to be learned consciously; in the later stages, consciousness enters as a monitor. At the beginning, consciousness is switched on all the time; later, it is used more selectively. Conscious rationality seems to be the door through which we must pass, although we do not need to stay stuck in the doorway forever (Chesterman 2000, pp. 79-80).

Just like when we are driving a car for the first few times, in which we think over all the steps learnt, because each of them requires a lot of effort and much concentration, translation also needs us to focus our attention on a number of procedures to deal with some options or handle some problems, but after doing each of the activities repeatedly over time, first with an instructor and then venturing on our own, all the steps turn into natural, automatic behaviour.

One of the difficulties, though, taking once again the same metaphor, is that there are almost no driving schools in town to properly equip the driver-to-be with the necessary tools for him/her to follow his/her own path.

Particularly, at undergraduate level, UTAD decided to offer 'English Translation Practice' as an option, after a semester of 'Theories and Techniques of Translation' as a mandatory course unit for students in Languages and Business Relations, while up to 2017-2018 both course units were compulsory and interdependent. Those students who did carry on the practical 'driving' lessons in 2018-2019 were not many and we acknowledge the low number of participants to

legendagem, uma tradução de uma canção ou a adaptação de um romance, e cada uma delas tem componentes específicas que não se podem transportar.] 
be a visible limitation to this study, besides the fact that they had to take their own "car", that is, their laptops or other devices and to download and install the software needed for them to work in classes. However, at the end of the road, which is certainly just the beginning of a new and probably more exciting journey, they fully understood that translation shall not be learnt through experience only, outside educational institutions, as a marginal or a hands-on activity with no initial guidance. Instead, as five students proved and three other students recognised, it is important to be able to work in groups, finding different solutions to problems and discussing them to reach conscious decision-making, if not throughout the process, at least at a later stage, when proofreading, revising and renewed proofreading.

By indulging in group discussions, accepting the challenges of each portfolio task, such as the subtitling one, the students learned that translation training in an academic environment strengthens Translation Competence, as they began to perceive similarities and to generalise from previously-taught situations, gaining new insights, the knowledge of translation strategies and tools that could be activated whenever needed. The final product, the portfolios, but also the process of producing the portfolio itself, are key to understanding critical approaches to problematic situations; they are iterative and dynamic working documents that exemplify the students' search for solutions to their puzzlements and reveal fascinating insights into the development of Translation Competence, and thus also contributing towards generating empirical findings to improve translation didactics.

\section{References}

Baker M (2011) In other words: a coursebook on translation. $2^{\text {nd }}$ Edition. London \& New York: Routledge.

Belsky S (2010) Making ideas happen: overcoming the obstacles between vision and reality. New York: Penguin Group.

Chesterman A (2000) Teaching strategies for emancipatory translation. In C Schäffner, B Adab (eds.), Developing Translation Competence (pp. 77-90). Amsterdam and Philadelphia: Benjamins.

Christian B (2011) The most human human: a defence of humanity in the age of the computer. London: Viking.

Czopik J (2014) Quality assurance process in translation. In Translating and the Computer 36. Proceedings of the AsLing Conference of 26-27 November 2015 (pp. 77-85). London/Geneva: Editions Tradulex.

Dewey J (1933) How we think: a restatement of the relation of reflective thinking in the educative process. Chicago: Henry Regnery.

Diaz-Cintas J (2015) Subtitling: theory, practice and research. In C Millán, F Bartrina (eds.), The Routledge Handbook of Translation Studies (pp. 273-287). London: Routledge.

Diaz-Cintas J, Remael A (2007) Audiovisual translation: subtitling. London, England: Routledge.

Dietzel S (2007) Example-based machine translation. Paper submitted in partial fulfilment of the requirements for a graded credit for the course "Human Language Technologies" in Winter Term 2006/07. Pilipps University Marburg: Grin Publishing. 
Eco U (2003) Mouse or rat? Translation as negotiation. London: Phoenix.

Galán-Mañas A (2016) Learning portfolio in translator training: the tool of choice for competence development and assessment. In The Interpreter and Translator Trainer 10(2): 161-182.

Ghassemiazghandi M, Mahadi T (2014) Losses and gains in computer-assisted translation: some remarks on online translation of English to Malay. In Translating and the Computer 36. Proceedings of the AsLing Conference of 26-27 November 2015 (pp. 194-201). London. Geneva: Editions Tradulex.

Gile D (2009) Basic concepts and models for interpreter and translator training. Amsterdam and Philadelphia: John Benjamins Publishing Co.

Karamitroglou F (1998) A proposed set of subtitling standards in Europe. Translation Journal 2(2): 1-15.

Karamitroglou F (2000) Towards a methodology for the investigation of norms in audiovisual translation. Amsterdam/Atlanta, GA: Rodopi.

Leech G (2014) The pragmatics of politeness. Oxford: Oxford University Press.

Massidda S, Casarini A (2017) Sub me do: the development of fansubbing in traditional dubbing countries - The case of Italy. In D Orrego-Carmona, Y Lee (eds.), NonProfessional Subtitling (pp. 63-83). Newcastle Upon Tyne: Cambridge Scholars Publishing.

Nida EA (1981) Translators are born not made. The Bible Translator 32(4): 401-405.

O'Brien S (2012) Translation as human-computer interaction. Translation Spaces 1(1): $101-122$.

Orozco M (2000) Building a measuring instrument for the acquisition of translation competence in trainee translators. In C. Schäffner \& B. Adab (Eds.), Developing Translation Competence (pp. 199-214). Amsterdam: John Benjamins.

PACTE (2003) Building a translation competence model. In F Alves (ed.), Triangulating Translation: Perspectives in Process Oriented Research (pp. 43-46). Amsterdam/ Philadelphia: John Benjamins.

Poibeau T (2017) Machine translation. Cambridge, Massachusetts: The MIT Press.

Pym A (2014) Exploring translation theories. London: Routledge.

Sofer M (2013) The global translator's handbook. Lanham: Taylor Trade Publishing.

Tergui S (2016) Economic translation: challenges and hindrances. In K Papaja, C Can (eds.), Language in Focus: Exploring the Challenges and Opportunities in Linguistics and English Language Teaching (ELT) (pp. 371-387). Newcastle upon Tyne: Cambridge Scholars Publishing.

Vasilescu R (2014) Ethical issues in machine translation. In Linguistic and Philosophical Investigations, Volume 13 (pp. 227+). Addleton Academic Publishers. 
